\title{
Target effector role of vascular endothelium in the inflammatory response: insights from the clinical trial of anti-TNF $\alpha$ antibody in rheumatoid arthritis
}

\author{
Ewa Paleolog
}

\begin{abstract}
Rheumatoid arthritis (RA) is characterised by chronic joint inflammation and infiltration by cells from the blood, especially activated $T$ cells and macrophages, together with formation of new blood vessels. The overgrowth of the synovial lesion results eventually in destruction of cartilage and bone. Cytokines play a major role in $\mathbf{R A}$, both in systemic inflammatory processes, such as induction of acute phase protein synthesis, and in the stimulation of new blood vessel development and recruitment of leucocytes to developing lesions. The focus for the interplay of many cytokines is the endothelium, the lining layer of the vasculature. This is the primary target for circulating mediators, and it controls the traffic of cells and molecules from the bloodstream into underlying tissues. Targeting the action of individual cytokines-for example, using antibody against tumour necrosis factor $\alpha$ (TNFa), has been shown to be very effective in the treatment of RA. Blockade of TNF $\alpha$ activity results in deactivation of the endothelium, manifested as reduced expression of adhesion molecules and chemoattractant cytokines, leading to diminished trafficking of inflammatory cells to synovial joints. In addition anti-TNFa decreases circulating levels of the potent angiogenic cytokine VEGF, suggesting that new blood vessel formation, and hence the supply of nutrients to the growing synovial lesion, is also affected. These observations lend further support to the hypothesis that interruption of a component of the cytokine network in RA may modulate disease progression, and point the way towards the development of new therapeutic strategies for the treatment of chronic inflammatory disease states. (F Clin Pathol: Mol Pathol 1997;50:225-233)
\end{abstract}

Keywords: rheumatoid arthritis; endothelium; tumour necrosis factor $\alpha$
Rheumatoid arthritis (RA) is a disabling disease of multiple joints with a prevalence of about $1 \%$ of the population. The lesion in RA is characterised by chronic inflammation and infiltration by cells from the blood, chiefly activated memory $\mathrm{CD}^{+} \mathrm{T}$ cells and macrophages, together with prominent formation of new blood vessels. ${ }^{12}$ This leads in most cases to the destruction of cartilage and bone, as a consequence of the invasion of these tissues by the hyperplastic synovial pannus. The development of lesions in RA, as well as in other inflammatory disease states, is controlled by the relative balance of a variety of signals including cytokines, which are known to be major mediators of immunity, cell growth, and inflammation in vivo. Cytokines play a key role in the pathogenesis of RA, both in systemic inflammatory processes, such as upregulation of acute phase protein synthesis, and in the stimulation of new blood vessel development and recruitment of leucocytes into the synovial tissue. $^{34}$

The focal point for the interplay of cytokines is the vascular endothelium, the lining layer of the vasculature. This is the primary target for the action of circulating mediators, and thus controls the traffic of cells and molecules from the bloodstream into underlying tissues. The "cross-talk" between endothelium, leucocytes, and pro-inflammatory or immunomodulatory cytokines fulfils a homeostatic function and acts as a rapid response facility in situations of injury or infection, but may also in appropriate circumstances perpetuate disease states such as RA. ${ }^{5}$ The increased mass of the pannus in RA also necessitates a supply of nutrients and oxygen, and proliferation of endothelial cells to develop a capillary network is also regulated by cytokines. This review focuses on the function of endothelium in the pathogenesis of arthritis, especially on the likely effects on endothelial cells of cytokines produced in RA, in particular tumour necrosis factor $\alpha$ (TNF $\alpha$ ), in relation to current concepts on the development of RA in vivo. 
Cytokine expression in RA: a key role for TNFa

Cytokine mRNA and protein expression in synovial tissue has been analysed by several groups and it is now apparent that many cytokines are abundant in RA. These include pro-inflammatory cytokines such as TNF $\alpha$ and interleukin (IL)-1; chemokines, namely IL-8, monocyte chemoattractant protein-1 (MCP1), Gro $\alpha$, ENA-78, and MIP-1 $\alpha$; immunomodulatory cytokines such as transforming growth factor $\beta$ (TGF $\beta$ ) and IL-10; and proand anti-angiogenic cytokines such as vascular endothelial growth factor (VEGF), fibroblast growth factor (FGF), and platelet derived growth factor (PDGF). ${ }^{36-14}$ These studies indicate that synovial cytokine expression in pathological states such as RA may be prolonged. Moreover, the plethora of cytokines detected in RA suggested the existence of a hierarchy in terms of importance in the pathogenesis of RA, and this concept was addressed in a series of studies at the Kennedy Institute using cultured synovial joint cells as an in vitro model system of human RA. These enzymatically dissociated cells, which are a heterogeneous population made up predominantly of macrophages, lymphocytes, and fibroblasts, were found spontaneously to secrete a profile of cytokines resembling that detected in synovial biopsies by immunohistology, including TNF $\alpha$, IL-1, IL10 , granulocyte-macrophage colony stimulating factor (GM-CSF), VEGF and TGF $\beta .^{15-19} \mathrm{It}$ was subsequently demonstrated that addition of antibody to $T N F \alpha$ markedly reduced production of IL-1, IL-6, IL-8, VGEF, and GM-CSF. Conversely, addition of IL-1 receptor antagonist (IL-1 ra) partially reduced secretion of IL- 6, IL-8, and VEGF, but had no effect on TNF $\alpha$ production. ${ }^{17} 2021$ Taken together these results led to the following hypotheses: in $\mathrm{RA}$, and possibly other inflammatory disease states, pro-inflammatory cytokines are linked in a sequence resembling an electrical circuit in series, with TNF $\alpha$ at the apex of the cascade in $\mathrm{RA}$ inducing production of $\mathrm{IL}-1$, and both TNF $\alpha$ and IL-1 inducing downstream cytokines such as IL-6, IL-8, VGEF, and GM-CSF. The presence of a number of antiinflammatory components, such as IL-10, IL-1ra, and soluble forms of receptors for $\mathrm{TNF} \alpha$, also implied that there may exist in vivo a balance between pro- and anti-inflammatory mediators, with a disequilibrium favouring the pro-inflammatory side in RA. ${ }^{34}$

The concept of a pivotal role for $\mathrm{TNF} \alpha$ in RA pathogenesis was validated in our laboratory in an animal model of arthritis, in which DBA/1 mice were injected with bovine type II collagen, resulting in a chronic erosive arthritis typified by cartilage loss and bone erosion. Treatment of these mice after disease onset with anti-TNF $\alpha$ was found to inhibit the development of arthritis, and significantly reduced cartilage and bone destruction. ${ }^{22}$ Further supportive evidence was derived from mice carrying a human TNF $\alpha$ transgene, in which the AU-rich 3' untranslated region was replaced by the stable $\beta$ globin $3^{\prime}$ flanking sequences, resulting in overexpression of human TNFa. Such mice were found to develop chronic erosive arthritis from 4-8 weeks of age, which could be completely prevented by blocking the activity of human $\mathrm{TNF} \alpha .^{23}$ Backcrossing of these TNF $\alpha$ transgenic mice onto the arthritis susceptibleo $\mathrm{DBA} / 1$ background resulted in progressive acceleration of arthritis with successive generations of interbreeding with $\mathrm{DBA} / 1$ mice. ${ }^{24}$

The reduction in pro-inflammatory cytokin $\stackrel{\stackrel{5}{+}}{+}$ production by anti-TNF $\alpha$ antibody in RA joint? cultures in vitro, coupled with the beneficia effect of anti-TNF $\alpha$ in murine collagen induced arthritis and the data from $T N F a$ transgenic mice, provided the rationale fores clinical trials of anti-TNF $\alpha$ antibody in patientso with active and longstanding $R A$.

\section{Clinical trials of TNF $\alpha$ blockade in RA}

The investigation of in vivo TNF $\alpha$ blockade in RA involved the use of cA2, a high affinity chi-o meric anti-TNF $\alpha$ monoclonal antibody, con sisting of human $\operatorname{IgG} 1 \kappa$ and mouse FVN containing the binding region for humano TNF $\alpha$. The results of multiple clinical trials of cA2, both open label and randomised, double blind, placebo controlled studies, clearly dem-0ิ0 onstrated that treatment of patients with RAD with antibody to TNF $\alpha$ led to significant improvements in clinical and laboratory para-e meters (joint tenderness, swelling, morning stiffness, C reactive protein levels, erythrocyteo sedimentation rates). ${ }^{25}{ }^{26}$ For example, in as multicentre, double blind trial of anti-TNF $\alpha$ 命 patients were treated with a single infusion of either placebo $(0.1 \%$ human serum albumin $)$ or $\mathrm{cA} 2$ at 1 and $10 \mathrm{mg} / \mathrm{kg}$. The primary endô을 point of the study was the achievement at week ${ }_{5}^{3}$ 4 of a Paulus $20 \%$ response. This is a compos ite disease activity index defined as significant improvement in at least four of six independent variables - that is, at least $20 \%$ improvement in continuous variables (tender and swollen joint scores, duration of morning stiffness, erythrocyte sedimentation rate) and at least grade 2 improvement in patient's and observer's assess-음 ment of disease severity. By week $4,79 \%$ of patients receiving the higher dose of $\mathrm{cA} 2 \stackrel{\mathrm{I}}{=}$ achieved a $20 \%$ Paulus response, compared $N$ with $44 \%$ of patients in the $1 \mathrm{mg} / \mathrm{kg} \mathrm{cA} 2 \mathrm{~N}$ treated group, and only $8 \%$ of placebo treated patients. The infusions of cA2 were well toler- $\omega$ ated, and of the 72 initially randomised patients only two had severe adverse events, one of which was judged possibly to be related? to treatment with cA2.

The successful treatment of RA patients with anti-TNF $\alpha$ provided an invaluable tool to analyse the underlying pathogenic mechanisms of inflammation in RA. Modulation of the activa-O tion status of vascular endothelium appears to be an important consequence of anti-TNF $\alpha$ O therapy, and subsequent sections will discuss in further detail the insights we have gained from? these studies.

Mechanism of action of anti-TNFa in RA: effect on cell trafficking

The striking effectiveness of TNF $\alpha$ blockade in vivo prompted the following question-what is 
the mode of action of anti-TNF $\alpha$ in vivo? The cytokine cascade hypothesis suggested that suppression of the cytokine production is likely to be a cause of part of the therapeutic benefit of anti-TNF $\alpha$, and indeed a rapid downregulation of circulating IL- 6 concentrations in RA patients following anti-TNF $\alpha$ therapy has been observed (unpublished data). However, in many patients the clinical benefit of anti-TNF $\alpha$ antibody was prolonged (up to 26 weeks), and appeared to outlast the effective cytokine neutralising levels of anti-TNF $\alpha$ in the serum of cA2 treated individuals. Another possible mechanism that may account for these prolonged effects of anti-TNF $\alpha$ could be reduced leucocyte trafficking to the synovial joint, as infiltration of leucocytes into arthritic joints is clearly an integral component of the development of synovial lesions. ${ }^{28}$ In rats with active arthritis anti-TNF $\alpha$ improved clinical scores and inhibited accumulation in the joints of radioactively labelled leucocytes. ${ }^{29}$ Together, these results indicate that endogenously produced cytokines such as TNF $\alpha$ and IL-1 contribute directly to leucocyte recruitment to joints and hence to inflammatory changes that occur during RA.

To extravasate into the synovial joint, the normal mobility within the blood vessels of the circulating cells must be overcome, resulting in a localised arrest of leucocytes at relevant sites, a process dependent on the expression by endothelium of adhesion molecules for leucocytes, including E-selectin (CD62E), intercellular adhesion molecule-1 (ICAM-1, CD54) and vascular cell adhesion molecule-1 (VCAM-1, CD106). ${ }^{30-32}$ E-selectin (also called endothelial-leucocyte adhesion molecule-1) mediates the early phase of neutrophil binding, as well as binding eosinophils, basophils, monocytes, and certain subsets of $\mathrm{T}$ cells. ${ }^{33}$ The primary members of the immunoglobulin superfamily expressed by endothelial cells are VCAM-1, ICAM-1, ICAM-2, MAdCAM-1, and platelet-endothelial cell adhesion molecule- 1 . In terms of RA, the most pertinent molecules are the mononuclear cell receptors VCAM-1 and ICAM-1, which, like E-selectin, also bind neutrophils. ${ }^{33}{ }^{34}$ The feature common to E-selectin, ICAM-1, and VCAM-1 is their inducibility on endothelium by cytokines such as $\mathrm{TNF} \alpha$, which induces a range of responses on endothelial cells. This has been shown by several groups, including our own, to occur via activation of a series of intracellular signalling pathways including tyrosine kinase enzymes. ${ }^{35-37}$ We and others have shown that inhibition of TNF $\alpha$ binding to its cell surface receptors on cultured human umbilical vein endothelial cells significantly reduces responses to $\mathrm{TNF} \alpha$, such as expression of adhesion molecules and production of chemoattractant cytokines such as IL-8. ${ }^{38}{ }^{39}$ Using sections of RA synovial membranes, studies from our laboratory have also localised both TNF $\alpha$ and its receptors to endothelium. ${ }^{40}{ }^{41}$ The enrichment in RA synovial infiltrates for monocytic cells and $\mathrm{T}$ cells of the $\mathrm{CD}^{+} \mathrm{CD}^{+} 5 \mathrm{RO}^{+}$ phenotype suggests selection for particular leucocyte subsets, which is governed by the relative levels of expression on endothelium and leucocytes themselves of appropriate receptors and their counter ligands. Over the past few years there have been a number of immunohistochemical analyses using normal and arthritic synovial tissue, documenting alterations in the pattern of expression of adhesion molecules in patients with RA. For example, it has been shown that antibody to E-selectin strongly stains endothelium in RA synovium, predominantly on venules and capillaries, whereas in osteoarthritic (OA) sections anti-E-selectin stained a substantially lower percentage of blood vessels and fewer endothelial cells. ${ }^{42}$ In addition, RA synovial endothelial cells were found to express increased levels of VCAM-1, ICAM-1, and ICAM-3, although in contrast to E-selectin, staining was also detectable on other cell types, including synovial tissue macrophages (VCAM-1, ICAM-1, and ICAM-3), fibroblasts (ICAM-1) and some lymphocytes (ICAM-1). ${ }^{42-45}$ It is clear, therefore, that overexpression of components of the leucocyte extravasation pathway (adhesion molecules or chemoattractant cytokines) occurs in RA, and that RA treatment such as anti-TNF $\alpha$ may exert their effects by regulation of leucocyte trafficking.

To address the question of whether leucocyte infiltration was modulated by anti-TNF $\alpha$ treatment, the immunohistological features of RA synovial biopsy specimens after infusion of cA2 were studied. At least five separate biopsy samples from 12 patients, who received either 10 or $20 \mathrm{mg} / \mathrm{kg}$ anti-TNF $\alpha$, were stained for E-selectin, VCAM-1, and CD3 (to measure T cell infiltration) and were scored by independent observers. In addition to a marked reduction in the degree of cellular infiltration, thickness of the lining layer, and the number of lymphoid aggregates of the RA membrane after $c A 2$, a significant $(p<0.05)$ decrease in the expression of CD3, E-selectin, and VCAM-1 was observed. For example, the mean proportion of blood vessels expressing E-selectin in paired synovial biopsies taken before and after four weeks of anti-TNF $\alpha$ treatment was decreased from $18.6 \%$ (mean of at least three samples per patient) to $9.1 \%{ }^{46}{ }^{47}$ However, these studies were complicated by the requirement for serial synovial biopsy samples, and the recent identification of soluble forms of adhesion molecules permitted a more detailed and quantitative analysis of the effect of therapy on leucocyte-endothelial cell interactions. Circulating E-selectin, ICAM-1, and VCAM-1 derived from proteolytic cleavage of the surface form have been described. ${ }^{48-50}$ Elevated serum concentrations of adhesion molecules have been observed in $\mathrm{RA}^{51-53}$ and in a number of other disease states, such as diabetes and tuberculosis, although in RA only ICAM-1 and VCAM-1 appear to correlate with disease severity. ${ }^{5455}$

We measured by ELISA serum concentrations of E-selectin, ICAM-1, and VCAM-1 in patients who received a single infusion of either placebo or cA2. We found that circulating E-selectin concentrations were raised in RA patients, but were unchanged following 
Table 1 Selective effects of anti-TNFa antibody cA2 on leucocyte recruitment in patients with rheumatoid arthritis

\begin{tabular}{llll}
\hline & $\begin{array}{l}\text { Placebo } \\
(n=24)\end{array}$ & $\begin{array}{l}1 \mathrm{mg} / \mathrm{kg} c \mathrm{cA2} \\
(n=23)\end{array}$ & $\begin{array}{l}10 \mathrm{mg} / \mathrm{kg} \mathrm{cA2} \\
(n=21)\end{array}$ \\
\hline $\begin{array}{l}\text { Serum } \\
\text { E-selectin }\end{array}$ & $-1 \%$ & $-7 \% \star$ & $-24 \% \star \star \star$ \\
$\begin{array}{l}\text { Serum } \\
\text { ICAM-1 }\end{array}$ & $+9 \%$ & $-1 \%$ & $-29 \% \star \star \star$ \\
$\begin{array}{l}\text { Serum } \\
\quad \text { VCAM-1 }\end{array}$ & $+4 \%$ & $+9 \%$ & $-1 \%$ \\
$\begin{array}{c}\text { Lymphocyte } \\
\text { counts }\end{array}$ & $-5 \%$ & $+17 \% \star$ & $+36 \% \star \star \star$ \\
Serum IL-8 & $+14 \%$ & $+17 \%$ & $-47 \% \star \star \star$ \\
\hline
\end{tabular}

Values are expressed as median percentage change relative to pre-infusion levels four weeks after a single infusion of placebo or cA2. Significant differences were determined compared with change in the placebo treated group by Mann-Whitney $U$ test and were adjusted using the Bonferroni correction for comparisons between multiple groups.

${ }^{\star} \mathrm{p} \leqslant 0.05 ;{ }^{\star \star \star} \mathrm{p} \leqslant 0.001$. $^{56}$

placebo treatment for the four weeks that samples were available. In contrast, serum E-selectin concentrations were decreased in both of the anti-TNF $\alpha$-treated groups. For example, one week after cA2 infusion median E-selectin concentrations decreased by $13 \%$ in the $1 \mathrm{mg} / \mathrm{kg}$ cA2 treated group ( $\mathrm{p}<0.05 \mathrm{com}-$ pared with change in placebo group), and by $26 \%$ in the $10 \mathrm{mg} / \mathrm{kg}$ cA2 treated group ( $p<0.001$ compared with change in placebo group). Similarly, soluble ICAM-1 concentrations did not change substantially at any time in the placebo patients, whereas in both sets of cA2 treated patients serum ICAM-1 decreased significantly $(p \leqslant 0.01$ compared with change in placebo group) one week after infusion. However, serum ICAM-1 concentrations returned to pre-infusion values more rapidly than E-selectin, which was still decreased four weeks after cA2 infusion. Finally, serum VCAM-1 concentrations were raised in RA patients, but these were not significantly affected by antiTNF $\alpha$ at any time ${ }^{4656}$ (table 1). Release of soluble adhesins has been found to correlate with expression of these molecules on the surface of cytokine activated endothelial cells; therefore, raised concentrations in RA may signify overexpression of endothelial cell surface equivalents. ${ }^{57}$ Although the cellular origin of the serum adhesion molecules has not been defined, E-selectin is expressed specifically on endothelium, and hence alterations in serum concentrations of this adhesion molecule in disease states may reflect changes in the endothelial cell phenotype in vivo. The reason for the discrepancy between the effect of anti-TNF $\alpha$ therapy on VCAM-1 expression on synovial biopsies and the absence of an effect on serum VCAM-1 is unclear, but may be related to the fact that serum VCAM-1 is not only endothelial cell derived. The in vivo roles of these soluble adhesion molecules are unclear, although immobilised soluble VCAM-1 and E-selectin have been found to support the binding of human leucocytes and leucocyte cell lines. ${ }^{4950} 52$

In parallel, anti-TNF $\alpha$ treated patients exhibited a rapid rise in circulating lymphocyte counts following cA2 infusion, with the earliest increase observed on day 1 after infusion. The increase in circulating lymphocytes persisted over the course of the study in the high dose
cA2 treated patients (median increase at week 4 equivalent to $36 \%$ ) (table 1 ). To determine whether the changes in serum E-selectin and ICAM-1 concentrations and peripheral blood lymphocyte counts correlate with the degree of $z$ disease amelioration in individual patients, we으 subdivided anti-TNF $\alpha$ treated ( 1 and $10 \mathrm{mg} / 0$ $\mathrm{kg} \mathrm{cA2}$ ) patients into those in whom a clinical benefit (20\% Paulus response) was either $\overrightarrow{\vec{F}}$ absent or present at week 4 . We found that in the patients who did not meet the $20 \%$ Paulus criteria at week 4 , the magnitude of the change $\frac{\bar{\sigma}}{\bar{s}}$ in E-selectin ( $5 \%$ reduction relative to pre- $\widehat{\Phi}$ infusion values) was significantly lower than in patients in whom a $20 \%$ Paulus response was ${ }^{\infty}$ observed at this time (median reduction in $\vec{\circ}$ E-selectin levels $23 \%$, p $<0.01$ compared with $\overrightarrow{\vec{\omega}}$ absence of $20 \%$ Paulus by Mann-Whitney U test). Similarly, the median reductions in 3 ICAM-1 concentrations were $1 \%$ (absence of $20 \%$ Paulus) and $23 \%$ (presence of 20\% Paulus) relative to pre-infusion values $(p<0.01 \mathrm{~N}$ compared with absence of $20 \%$ Paulus). Com- $N$ parable analyses were performed for lym-을 phocyte counts at week 4 after infusion of antiTNF $\alpha$. For the individuals in whom the $20 \%$ O Paulus criteria were not met there was no change in the median value for circulating lymphocyte levels (median increase $0 \%$ relative to $\vec{\theta}$ week 0) compared with an increase of $29 \%$ in 8 the patients in whom a $20 \%$ Paulus response was observed ( $p<0.05$ compared with absence of $20 \%$ Paulus) ${ }^{56}$ These findings confirm the clinical relevance of the changes in serum E-selectin and ICAM-1 and circulating lymphocyte counts.

Together with the observation of reduced cellularity and adhesion molecule expression in RA synovial biopsy specimens after cA2, our demonstration of reciprocal changes in serum adhesion molecule concentrations and circulating lymphocyte counts suggests that de- $\frac{0}{3}$ creased endothelial cell expression of adhesion molecules may contribute to the rise in periph- 윽 eral blood lymphocyte counts. Such an effect may be either a direct result of the in vivo neutralisation of TNF $\alpha$ by cA2, and hence dimin- $-\frac{7}{0}$ ished endothelial activation, or a secondary effect, resulting from the down-modulation of 0 macrophage/monocyte responses, such as pro- $N$ duction of pro-inflammatory cytokines that can activate endothelium. However, the rapid time 0 course of the alterations in concentrations of serum adhesion molecules and lymphocyte $\mathbb{D}$ counts (earliest observed decrease $1-3$ days) is $\stackrel{\oplus}{+}$ strongly suggestive of a primary effect of $\frac{T}{T}$ anti-TNF $\alpha$ on endothelial cell activation and $\stackrel{+}{\circ}$ thus on leucocyte trafficking. Nevertheless, $\stackrel{\square}{\stackrel{P}{P}}$ leucocyte trafficking requires not only expres- $\stackrel{\square}{\square}$ sion of adhesion molecules by vascular endothelium, but also a second signal, provided $\Omega$ by chemotactic factors such as chemokines. In this context, there is evidence from our laboratory of decreased serum concentrations in patients with RA of both IL- 8 and MCP- 1 after anti-TNF $\alpha$ infusion (table 1), together with reduced expression of IL- 8 and MCP-1 in synovial biopsy specimens (unpublished data), indicating that anti-TNF $\alpha$ may downregulate both arms of the leucocyte trafficking system. 
This hypothesis can only be investigated further by direct measurements of the trafficking of labelled leucocytes to the joints, and these studies are currently in progress.

However, generation of a hypercellular synovial membrane and invasive pannus in $R A$ is dependent on a supply of nutrients, as well as inflammatory cells and molecules, and indeed one of the earliest observed features of RA is the development of a new vascular network within the synovium that serves to promote delivery of cells and nutrients to the invading pannus. Many cytokines are thought to play a role in regulating angiogenesis, prompting the proposal that anti-TNF $\alpha$ may also exert effects on new blood vessel formation in RA. The results of our preliminary study, which examined the effect of cA2 on the serum concentrations of the angiogenic cytokine VEGF, are discussed in the following section.

\section{Mechanism of action of anti-TNFa in RA: effect on mediators of angiogenesis}

Formation of new blood vessels is an integral component of embryonic development, but in adults occurs only rarely (during wound healing or as part of the female reproductive cycle). However, angiogenesis has been demonstrated to occur in a range of pathological conditions such as cancer, psoriasis, and RA, which have as a consequence been classified as angiogenesis dependent diseases. ${ }^{6061}$ Formation of new blood vessels is controlled by a range of factors, most of which are proteins and include many cytokines, exerting both proangiogenic (for example, Gro $\alpha, T G F \beta$ ) and anti-angiogenic (for example, IP-10) effects. ${ }^{62}$

The importance of new blood vessel formation in the maintenance of arthritic disease has been demonstrated in a series of studies in which angiogenesis inhibitors were found to prevent onset of collagen induced arthritis in rats and significantly suppressed established disease, in parallel with pronounced inhibition of pannus formation. ${ }^{63-65}$ In the context of the human arthritic joint, a range of proangiogenic cytokines have been detected in RA synovial biopsy sections, including FGF, PDGF, TGF $\beta$, TNF $\alpha$ itself, and chemokines such as IL-8 and Groa..$^{6-9}{ }^{14-16}$ Recently, a novel family of angiogenic cytokines has emergedthe VEGF family. The original member, VEGF, a potent endothelial mitogen and inducer of vascular permeability changes, is unique by virtue of its selective effects on endothelial cell proliferation, and plays a critical role in pathological angiogenesis and permeability changes-for example, in tumours, RA, psoriasis, diabetic retinopathy, and atherosclerosis. ${ }^{66-69}$ VEGF is both an endothelial cell selective mitogen and a modulator of changes in vascular permeability, both of these activities are of potential relevance in the pathogenesis of RA. Expression of VEGF mRNA by RA lining layer cells has been reported, and immunohistochemical analyses of RA synovial biopsies revealed VEGF expression by synovial lining layers and endothelial cells lining small blood vessels within the pannus. Moreover, microvascular endothelial cells in the vicinity of VEGF positive cells expressed mRNA for both VEGF receptor subtypes (flt1/VEGF-R1 and KDR/VEGF-R2)..$^{13} 7071$

Although to date the role of $T N F \alpha$ in the regulation of VEGF release has not been fully elucidated, we proposed that the high degree of vascularisation of the RA pannus and the presence of VEGF in RA synovial tissue biopsies may be reflected in correspondingly raised serum concentrations of VEGF, and moreover that anti-TNFa may modulate circulating VEGF concentrations. As a follow up to the study of serum adhesion molecules, we assayed by ELISA serum VEGF concentrations in RA patients from the placebo controlled trial of cA2. We observed that median serum VEGF concentrations in non-arthritic individuals $(160 \mathrm{pg} / \mathrm{ml})$ were much lower than in patients with active RA (median $503 \mathrm{pg} / \mathrm{ml}, \mathrm{p}<0.001$ compared with non-RA), and that in patients with RA, VEGF correlated with circulating C-reactive protein, a marker of inflammatory disease activity. We investigated whether these raised serum VEGF concentrations in RA could be altered by anti-TNF $\alpha$ therapy, and observed that treatment of RA patients with anti-TNF $\alpha$ significantly reduced serum VEGF in a time and dose dependent manner. In patients who received $10 \mathrm{mg} / \mathrm{kg} \mathrm{cA} 2$, the maximal change in serum VEGF concentrations was achieved at week 3 (decrease $42 \%$, $\mathrm{p}<0.001$ compared with pre-infusion and change in patients given placebo). Even four weeks after anti-TNF $\alpha$ treatment, serum VEGF concentrations were significantly below pre-infusion values (table 2). Reductions in serum VEGF concentrations were more pronounced and more persistent than the corresponding changes in serum E-selectin and ICAM-1. On the basis of these clinical data alone it was not possible to conclude whether TNF $\alpha$, IL- 1 or another cytokine are predominantly involved in the induction of VEGF in vivo, as blockade of TNF $\alpha$ activity in vivo by cA2 would also result in the down-modulation of downstream cytokines such as IL-1. Nonetheless, these observations provided compelling evidence that VEGF production in vivo is regulated by pro-inflammatory cytokines. ${ }^{19}$

To investigate furhter the mechanism of action of anti-TNF $\alpha$ antibody in RA, we analysed the role of pro-inflammatory

Table 2 Effect of anti-TNFa antibody cA2 treatment on serum concentrations of angiogenic VEGF in patients with rheumatoid arthritis

\begin{tabular}{|c|c|c|c|c|}
\hline \multirow[b]{2}{*}{ Week } & \multicolumn{2}{|c|}{ Placebo $(n=24)$} & \multicolumn{2}{|c|}{$10 \mathrm{mg} / \mathrm{kg} \mathrm{cA} 2(\mathrm{n}=21)$} \\
\hline & $\begin{array}{l}V E G F \\
(p g / m l)\end{array}$ & $\begin{array}{l}\text { Change } \\
(\%)\end{array}$ & $\begin{array}{l}V E G F \\
(p g / m l)\end{array}$ & $\begin{array}{l}\text { Change } \\
(\%)\end{array}$ \\
\hline 0 & 517.1 & - & 438.9 & - \\
\hline 1 & 547.5 & -6 & 439.8 & $-26^{\star \star \star}$ \\
\hline 2 & 577.7 & -1 & 316.2 & $-40^{\star \star \star}$ \\
\hline 3 & 554.3 & +2 & 319.3 & $-42^{\star \star \star}$ \\
\hline 4 & 549.6 & -5 & 354.1 & $-39^{\star \star \star}$ \\
\hline
\end{tabular}

Patients received a single infusion of either placebo or cA2. Values are expressed as median VEGF and median percentage change in VEGF relative to pre-infusion levels. Significance was determined compared with change in pre-infusion levels by Wilcoxon rank test and was adjusted using the Bonferroni correction for comparisons between multiple groups. $\star \star \star \mathrm{p} \leqslant 0.001$ (unpublished data). 
cytokines in the regulation of VEGF release in vitro from cells that may be postulated to contribute to enhanced circulating VEGF levels in RA. We observed that monocytic cells (THP-1) and human dermal microvascular endothelial cells (HMEC-1), as well as RA synovial membrane fibroblasts, secrete VEGF constitutively, and that TNF $\alpha$ can enhance the release of VEGF from monocytic and endothelial cells, but not from cultured fibroblasts. In contrast, IL-1 activation resulted in secretion of VEGF from endothelial cells and fibroblasts, but had no effect on monocytic cells. These data support our conclusion that decreased serum VEGF results from inhibition of cytokine activity following in vivo blockade of TNF $\alpha$ by cA2. The novel finding that microvascular endothelial cells - the putative target for VEGF action-release VEGF both constitutively and in response to TNF $\alpha$ and IL-1 provides a potential autocrine pathway to amplify the angiogenic effects of VEGF (unpublished data).

\section{Future perspectives}

The vascular endothelium can fulfil both a target and an effector function in the pathogenesis of inflammatory disease states, by virtue of its ability to regulate the delivery of cells and molecules and to respond to increased requirements for oxygen and metabolites by formation of a new vascular network. Many studies have demonstrated the presence of various adhesion molecules and chemokines at sites of inflammation - for example, in RA, ischaemiareperfusion injury, atherosclerosis, and vasculitis. In RA, in addition to enhanced expression of adhesion molecules, many of the features of the synovial environment suggest possible roles for chemokines, in that the large number of infiltrating leucocytes, especially the selective accumulation of memory $\mathrm{T}$ cells, could be a response to the elaboration of chemoattractant molecules. Several chemokines have been detected in RA, including IL-8, Groa, MCP-1, RANTES, ENA-78, MIP-1 $\alpha$, and MIP-1 $\beta$. These chemokines may be anchored on the cell surface, thereby ensuring a relatively high concentration of chemoattractants close to the blood vessel wall, and hence temporally and spatially restricted activation of circulating cells. ${ }^{72}$ It is becoming apparent that many antiinflammatory drugs modulate components of the adhesion-migration pathway, and our own data indicate that beneficial effects of antiTNF $\alpha$ in RA result at least in part from decreased endothelial activation (expression of adhesion molecules and production of chemokines such as IL-8 and MCP-1) and a resultant reduction in cell trafficking. Moreover, suppression of arthritis as a result of in vivo blockade of leucocyte adhesion (for example, with a monoclonal antibody to ICAM-1) has been demonstrated in both animal models of arthritis $^{73-76}$ and in human RA. ${ }^{77}$ It remains to be seen whether it will be possible to block adhesion selectively or extravasation as a means of successful therapy of inflammatory disease states.
One of the more exciting ideas in terms of understanding the mechanisms of disease pathogenesis is the realisation that new blood vessels are essential to maintain increased tissue mass, and inhibition of angiogenesis has as a consequence become a major goal for the 으 development of treatment strategies. We have $\bar{T}$

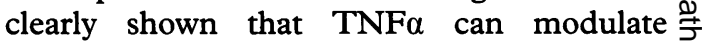
production of VEGF in vivo, although further studies (such as magnetic resonance imaging) are required to determine whether decreased $\bar{C}$ serum VEGF concentrations after anti-TNF $\alpha$ 음 therapy are paralleled by reduced angiogenesis. Our results suggest that VEGF and other com- $\stackrel{\mathbb{}}{\complement}$ ponents of the angiogenic pathway are a likely therapeutic target in RA, and that modulation $\overrightarrow{0}$ of VEGF expression may synergise with $\overrightarrow{\vec{H}}$ anti-TNF $\alpha$ treatment leading to long term $\vec{\omega}$ benefit. It is of interest that VEGF is also $\frac{2}{3}$ expressed in late stage human $\mathrm{OA}$, where an inflamed synovium, clinically indistinguishable or from RA pannus, is often observed. ${ }^{13} 70$ These $G$ results suggest of a role for VEGF in maintain- N ing the inflamed synovium in both RA and OA. Additional neovascularisation events also occur $\stackrel{ }{-}$ in early $\mathrm{OA}$, in which cartilage has been shown $\mathrm{O}$ to lose its avascularity, unlike normal cartilage, $\frac{9}{0}$ which remains relatively resistant to vascular invasion. Moreover, chondrocytes at the interface of cartilage and invading vasculature $\stackrel{\oplus}{\oplus}$ express VEGF, ${ }^{78}$ suggesting that the subchon-.dral changes observed in OA may be regulated by neovascularisation, possibly through VEGF. Based on the close association of angiogenesis and VEGF in arthritic disease it is therefore possible is that suppression of new blood vessel $\cong$ formation in both RA and OA could be of $\overrightarrow{0}$ therapeutic benefit. Inhibition of VEGF activity has certainly been effective in models of other diseases with pathogenic neovascularisation. For example, growth of tumours in mice is $\overline{0}$ blocked by anti-VEGF antibody and by administration of a dominant negative form of KDR/VEGF-R2 $2^{79}{ }^{80}$; soluble VEGF receptor $\delta$ chimeras have been shown to suppress VEGF $₹$ induced retinal neovascularisation ${ }^{81}$; and anti-음 sense to VEGF suppressed human glioblas- $\rightarrow$ toma angiogenicity and tumorigenicity. ${ }^{82}$

A complementary strategy would be to modulate selectively VEGF production, especially from the target cells for VEGF, namely endothelial cells. It has been shown in $a^{\omega}$ number of studies that IL- 1 and TNF $\alpha$ activate the nuclear factor NFkB, as well as the mitogen activated protein kinase p42/44 (ERK1/2) in fibroblasts and endothelial cells. ${ }^{36} 83$ In addition, a potent stimulus for VEGF release is 0 hypoxia, which is also a feature of arthritic joints, presumably because of raised intra- $\mathbb{\mathbb { Q }}$ articular pressure, which may at times exceedo the pressure within synovial capillaries resulting in movement induced synovial capillaryo occlusion. ${ }^{84}$ Perfusion insufficiency, and the resultant hypoxia, often induces a compensa- $-\bar{\partial}$ tory neovascularisation to satisfy the needs of developing tissue (for example, RA pannus or a developing tumour), and induction of VEGF and its receptors by hypoxia have been described. ${ }^{85}{ }^{86}$ Hypoxia increases the tyrosine kinase activity of c-src, and expression of 
dominant negative c-src was found to reduce VEGF production. Other studies have suggested that tumour suppressor genes such as VHL and p53 may downregulate VEGF at a post-transcriptional level. ${ }^{69} 87$ These signalling systems are potential targets for therapeutic intervention in the context of alterations in VEGF production. Treatment strategies that interfere with vascularisation and hence progression of growing tissue mass, such as the arthritic pannus or developing tumour, offer a promising approach to treatment of angiogenesis dependent disease.

It is also emerging that many activities of endothelial cells may overlap in terms of the responses they induce. For example, tissue factor, the principal initiator of coagulation in vivo, which is rapidly induced on endothelium by $\mathrm{TNF} \alpha,{ }^{39}$ may also control angiogenesis. Tumour cells transfected to overexpress tissue factor were found to release more VEGF than control transfectants ${ }^{88}$ suggesting that coagulation and angiogenesis may be intrinsically connected. Adhesion of leucocytes to endothelium and of endothelium to extracellular matrix proteins is also of paramount importance in the formation of new blood vessels. ${ }^{89}$ Integrin $\alpha V \beta 3$, which binds vitronectin, fibronectin, von Willebrand factor, fibrinogen, and thrombospondin, is expressed on newly formed blood vessels, ${ }^{90}$ although the mechanism by which $\alpha \mathrm{V} \beta 3$ functions in angiogenesis is unclear. Interestingly, soluble E-selectin and VCAM-1 were demonstrated to promote angiogenesis in rat cornea and induce chemotaxis of human endothelial cells, ${ }^{91}$ which may be of particular relevance in RA. Finally, chemokines, which are key regulators of leucocyte activation and selective extravasation exhibit both pro- and anti-angiogenic activities, ${ }^{62}$ thus integrating different elements of the endothelial response.

\section{Summary}

Many pathological states, such as RA, asthma, atherosclerosis, Crohn's disease, ischaemiareperfusion injury, graft rejection, vasculitis, and transplant rejection share common features of alterations in endothelial cell function, such as changes in adhesion molecule expression or neovascularisation, although the inciting events are widely different. The importance in arthritis of a series of cytokine mediated reactions associated with massive leucocyte infiltration and neovascularisation, make RA a potential paradigm for other inflammatory diseases. Increased understanding of the mechanisms of vascular endothelial responses may in the future lead to interventions designed to modulate endothelial activities - either by suppression of pro-inflammatory events such as leucocyte adhesion or by enhancement of antiinflammatory reactions such as release of antiangiogenic chemokines-and hence more successful treatment of inflammatory conditions.

1 Colville-Nash PR, Scott DL. Angiogenesis and rheumatoid arthritis: pathogenic and therapeutic implications. Ann Rheum Dis 1992;51:919-25.

2 Sewell KL, Trentham DE. Pathogenesis of rheumatoid arthritis. Lancet 1993;341:283-6.

3 Feldmann M, Brennan FM, Maini RN. Role of cytokines in rheumatoid arthritis. Ann Rev Immunol 1995;14:397-440.
4 Feldmann M, Brennan FM, Maini RN. Rheumatoid arthritis. Cell 1996;85:307-10.

5 Ziff $M$. Role of the endothelium in chronic inflammatory synovitis. Arthritis Rheum 1991;34:1345-52.

6 Buchan G, Barrett K, Turner M, Chantry D, Maini RN, Feldmann $M$. Interleukin-1 and tumour necrosis factor mRNA expression in rheumatoid arthritis: prolonged production of IL-1 $\alpha$. Clin Exp Immunol 1988;73:449-55.

7 Chu CQ, Field M, Abney E, Zheng RQ, Allard S, Feldmann $\mathrm{M}$, et al. Transforming growth factor- $\beta 1$ in rheumatoid synovial membrane and cartilage-pannus junction. Clin Exp Immunol 1991;86:380-6.

8 Sano H, Forough R, Maier JA, Case JP, Jackson A, Engleka $\mathrm{K}$, et al. Detection of high levels of heparin binding growth factor-1 (acidic fibroblast growth factor) in inflammatory arthritic joints. F Cell Biol 1990;110:1417-26.

9 Remmers EF, Sano H, Wilder RL. Platelet-derived growth factors and heparin-binding (fibroblast) growth factors in the synovial tissue pathology of rheumatoid arthritis. Semin Arthritis Rheum 1991;21:191-9.

10 Koch AE, Kunkel SL, Harlow LA, Johnson B, Evanoff HL, Haines GK, et al. Enhanced production of monocyte chemoattractant protein-1 in rheumatoid arthritis. $\mathcal{F}$ Clin chemoattractant prot

11 Koch AE, Kunkel SL, Harlow LA, Mazarakis DD, Haines GK, Burdick MD, et al. Epithelial neutrophil activating peptide-78: a novel chemotactic cytokine for neutrophils in arthritis. F Clin Invest 1994;94:1012-18.

12 Koch AE, Kunkel SL, Harlow LA, Mazarakis DD, Haines GK, Burdick MD, et al. Macrophage inflammatory protein-1 alpha. A novel chemotactic cytokine for macrophages in rheumatoid arthritis. $\mathcal{f}$ Clin Invest 1994;93:9218 .

13 Koch AE, Harlow LA, Haines GK, Amento EP, Unemori EN, Wong WL, et al. Vascular endothelial growth factor. A cytokine modulating endothelial function in rheumatoid arthritis. F Immunol 1994;152:4149-56.

14 Koch AE, Kunkel SL, Shah MR, Hosaka S, Halloran MM Haines GK, et al. Growth-related gene product $\alpha$. A chemotactic cytokine for neutrophils in rheumatoid arthritis. F Immunol 1995;155:3660-6.

15 Lafyatis R. Thomson NL, Remmers ER, Flanders KC, Roche NS, Kim SJ. Transforming growth factor- $\beta$ production by synovial tissues from rheumatoid arthritis patients and streptococcal cell wall arthritis rats. Studies on secretion by synovial fibroblast-like cells and immunohistological localisation. F Immunol 1989;143:1142-8.

16 Brennan FM, Zachariae CO, Chantry D, Larsen CG, Turner M, Maini RN, et al. Detection of interleukin 8 biological activity in synovial fluids from patients with rheumatoid arthritis and production of interleukin 8 rheumatoid arthritis and production of interleukin 8 mRNA by

17 Haworth C, Brennan FM, Chantry D, Turner M, Foxwell B, Maini RN, et al. Expression of granulocyte-macrophage colony-stimulating factor in rheumatoid arthritis: regulation by tumour necrosis factor- $\alpha$. Eur $\mathcal{F}$ Immunol 1991;21: 2575-9.

18 Katsikis P, Chu CQ, Brennan FM, Maini RN, Feldmann M. Immunoregulatory role of interleukin 10 (IL-10) in rheumatoid arthritis. $f$ Exp Med 1994;179:1517-27.

19 Withdrawn.

20 Brennan FM, Chantry D, Jackson A, Maini R, Feldmann $M$. Inhibitory effect of TNF $\alpha$ antibodies on synovial cell interleukin-1 production in rheumatoid arthritis. Lance 1989;ii:244-7.

21 Butler DM, Maini RN, Feldmann M, Brennan FM. Modulation of proinflammatory cytokine release in rheumatoid synovial membrane cell cultures with an anti-TNFa monoclonal; comparison with blockade of IL-1 using the recombinant IL-1 receptor antagonist. European Cytokine recombinant IL-1 recep

22 Williams RO, Feldmann M, Maini RN. Anti-tumor necrosis factor ameliorates joint disease in murine collagen-induced arthritis. Proc Nat Acad Sci U S A 1992;89:9784-8.

23 Keffer J, Probert L, Cazlaris H, Georgopoulos S, Kaslaris E, Kioussis D, et al. Transgenic mice expressing human tumour necrosis factor: a predictive genetic model of tumour necrosis factor: a predictive

24 Butler DM, Malfait AM, Mason LJ, Warden PJ, Kollias G, Maini RN, et al. DBA/1 mice expressing the human TNFa transgene develop a severe, erosive arthritis: characterisation of the cytokine cascade and cellular composition. $f$ Immunol 1997;159:2867-76.

25 Elliott MJ, Maini RN, Feldmann M, Long-Fox A, Charles $\mathrm{P}$, Katsikis $\mathrm{P}$, et al. Treatment of rheumatoid arthritis with chimeric monoclonal antibodies to TNF $\alpha$. Arthritis Rheum 1993;36:1681-90

26 Elliott MJ, Maini RN, Feldmann M, Kalden JR, Antoni C, Smollen JS, et al. Randomised double-blind comparison of chimeric monoclonal antibody to tumour necrosis factor $\alpha$ chimeric monoclonal antibody to tumour necrosis factor a (cA2) versus plac

7 Withdrawn.

28 Cronstein BN. Adhesion molecules in the pathogenesis of rheumatoid arthritis. Curr Opin Rheumatol 1994;6:300-4.

29 Issekutz AC, Meager A, Otterness I, Issekutz TB. The role of tumour necrosis factor-alpha and IL-1 in polymorphonuclear leucocyte and T lymphocyte recruitment to joint inflammation in adjucant arthritis. Clin Exp Immunol 1994. 97:26-32.

30 Carlos TM, Harlan JM. Leukocyte-endothelial adhesion molecules. Blood 1994;84:2068-101. 
31 Kansas GS. Selectins and their ligands: current concepts and controversies. Blood 1996;88:3259-87.

32 Luscinskas FW, Gimbrone MA. Endothelial-dependent mechanisms in chronic inflammatory leukocyte recruitment. Annu Rev Med 1996;47:413-21.

33 Pober JS, Gimbrone M Jr, Lapierre LA, Mendrick DL, Fiers $\mathrm{W}$, Rothlein R, et al. Overlapping patterns of activation of human endothelial cells by interleukin 1, tumor necrosis factor, and immune interferon. $\mathcal{F}$ Immunol 1986;137:1893 6.

34 Carlos TM, Schwartz BR, Kovach NL, Yee E, Rosso M, Osborn L, et al. Vascular cell adhesion molecule-1 mediates lymphocyte adherence to cytokine-activated cultured human endothelial cells. Blood 1990;76:965-70.

35 Paleolog EM, Aluri GA, Feldmann M. Contrasting effects of interferon $\gamma$ and interleukin 4 on responses of human vascular endothelial cells to tumour necrosis factor $\alpha$. Cytokine 1992;4:470-8.

36 Saklatvala J, Davis W, Guesdon F. Interleukin 1 (IL1) and tumour necrosis factor (TNF) signal transduction. Phil Trans $R$ Soc London B 1996;351:151-7.

37 Majewska E, Paleolog E, Baj Z, Kralisz U, Feldmann M, Tchorzewski $\mathrm{H}$. Role of tyrosine kinase enzymes in TNF- $\alpha$ and IL-1 induced expression of ICAM-1 and VCAM-1 in and IL-1 induced expression of ICAM-1 and VCAM-1 in
human umbilical vein endothelial cells. Scand 7 Immunol human umbilical

38 Slowik MR, De Luca LG, Fiers W, Pober JS. Tumor necrosis factor activates human endothelial cells through the p55 tumor necrosis factor receptor but the p75 receptor contributes to activation at low tumor necrosis factor concentration. Am f Pathol 1993;143:1724-30.

39 Paleolog EM, Delasalle SAJ, Buurman WA, Feldmann M. Functional activities of receptors for tumour necrosis factor- $\alpha(\mathrm{TNF}-\alpha)$ on human vascular endothelial cells. Blood 1994;84:2578-90.

40 Chu CQ, Field M, Feldmann M, Maini RN. Localization of tumor necrosis factor $\alpha$ in synovial tissue and at the cartilage-pannus junction in patients with rheumatoid arthritis. Arthritis Rheum 1991;34:1125-32.

41 Deleuran BW, Chu CQ, Field M, Brennan FM, Mitchell T, Feldmann M, et al. Localization of tumor necrosis factor receptors in the synovial tissue and cartilage-pannus junction in patients with rheumatoid arthritis. Implications for local actions of tumor necrosis factor alpha. Arthritis Rheum 1992;35:1170-8.

42 Koch AE, Burrows JC, Haines GK, Carlos TM, Harlan JM, Leibovich SJ. Immunolocalization of endothelial and leukocyte adhesion molecules in human rheumatoid and
osteoarthritic synovial tissues. Lab Invest 1991;64:313-20.

43 Johnson BA, Haines GK, Harlow LA, Koch AE. Adhesion molecule expression in human synovial tissue. Arthritis Rheum 1993;36:137-46.

44 El-Gabalawy H, Gallatin M, Vazeux R, Peterman G, Wilkins J. Expression of ICAM-R (ICAM-3), a novel counter-receptor for LFA-1, in rheumatoid and nonrheumatoid synovium. Arthritis Rheum 1994;37:846-54.

45 Szekanecz Z, Haines GK, Lin TR, Harlow LA, Goerdt S, Rayan G, et al. Differential distribution of intercellular adhesion molecules (ICAM-1, ICAM-2, and ICAM-3) and the MS-1 antigen in normal and diseased human synovia. Their possible pathogenetic and clinical significance in Their possible pathogenetic and clinical significance
rheumatoid arthritis. Arthritis Rheum 1994;37:221-31.

46 Maini RN, Elliott MJ, Brennan FM, Williams RO, Chu CQ, Paleolog E, et al. Monoclonal anti-TNF $\alpha$ antibody as a probe of pathogenesis and therapy of rheumatoid disease. Immunological Reviews 1995;144:195-223.

47 Tak PP, Taylor PC, Breedveld FC, Smeets TJM, Daha MR, Kluin PM, et al. Decrease in cellularity and expression of adhesion molecules by anti-tumor necrosis factor a monoclonal antibody treatment in patients with rheumatoid arthritis. Arthritis Rheum 1996;39:1077-81.

48 Gearing $\mathrm{AJH}$, Newman W. Circulating adhesion molecules in disease. Immunology Today 1993;14:506-12.

49 Lobb RR, Chi-Rosso G, Leone DR, Rosa MD, Bixler S, Newman BM, et al. Expression and functional characterization of a soluble form of endothelial-leukocyte adhesion molecule-1. F Immunol 1991;147:124-9.

50 Lobb R, Chi-Rosso G, Leone D, Rosa M, Newman B, Luhowskyj S, et al. Expression and functional characterization of a soluble form of vascular cell adhesion molecule-1. Biochem Biophys Res Commun 1991;178:1498-504.

51 Cush JJ, Rothlein R, Lindsley HB, Mainolfi EA, Lipsky PE. Increased levels of circulating intercellular adhesion molecule 1 in the sera of patients with rheumatoid arthritis. Arthritis Rheum 1993;36:1098-102.

52 Wellicome SM, Kapahi P, Mason JC, Lebranchu Y, Yarwood H, Haskard DO. Detection of a circulating form of vascular cell adhesion molecule-1: raised levels in rheumatoid arthritis and systemic lupus erythematosus. Clin Exp Immunol 1993;92:412-18.

53 Blann AD, McCollum CN, Steiner M, Jayson MIV Circulating adhesion molecules in inflammatory and
atherosclerotic vascular disease. Immunol Today 1995;16: atherosc

54 Aoki S, Imai K, Yachi A. Soluble intercellular adhesion molecule-1 (ICAM-1) antigen in patients with rheumatoid arthritis. Scand F Immunol 1993;38:485-90.

55 Mason JC, Kapahi P, Haskard DO. Detection of increased levels of circulating intercellular adhesion molecule 1 in some patients with rheumatoid arthritis but not in patients with systemic lupus erythematosus. Lack of correlation with levels of circulating vascular cell adhesion molecule 1 . Arthritis Rheum 1993;36:519-27.
56 Paleolog EM, Hunt M, Elliott MJ, Feldmann M, Maini RN, Woody JN. Deactivation of vascular endothelium by monoclonal anti-tumor necrosis factor $\alpha$ antibody in rheumatoid arthritis. Arthritis Rheum 1996;39:1082-91.

57 Leeuwenberg JF, Smeets EF, Neefies JJ, Shaffer MA, Cinek $\mathrm{T}$, Jeunhomme TM, et al. E-selectin and intercellular adhesion molecule-1 are released by activated human endothelial cells in vitro. Immunology 1992;77:543-9.

58 Pigott R, Dillon LP, Hemingway IH, Gearing AJ. Soluble 으 forms of E-selectin, ICAM-1 and VCAM-1 are present in the supernatants of cytokine activated cultured endothelial cells. Biochem Biophys Res Commun 1992;187:584-9.

59 Withdrawn.

60 Folkman J. Angiogenesis and angiogenesis inhibition: an $\overrightarrow{\bar{ज}}$ overview. EXS 1997;79:1-8.

61 Folkman J. Angiogenesis in cancer, vascular, rheumatoid and other disease. Nat Med 1995;1:27-31.

62 Hanahan D, Folkman J. Patterns and emerging mechanisms of the angiogenic switch during tumorigenesis. Cell 1996;86:353-64

63 Peacock DJ, Banquerigo ML, Brahn E. Angiogenesis inhibition suppresses collagen arthritis. $\mathcal{F}$ Exp Med 1992;175: $\mathcal{C}$

64 Oliver SJ, Banquerigo ML, Brahn E. Suppression of $\overrightarrow{0}$ collagen-induced arthritis using an angiogenesis inhibitor, AGM-1470, and a microtubule stabilizer, taxol. Cell Immu- $\vec{\omega}$ nol 1994;157:291-9.

65 Oliver SJ, Cheng TP, Banquerigo ML, Brahn E. Suppres- 3 sion of collagen-induced arthritis by an angiogenesis inhibitor, AGM-1470, in combination with cyclosporin: Cell Immunol 1995;166:196-206.

66 Dvorak HF, Detmar M, Claffey KP, Nagy JA, Van de Waterĩ $\mathrm{L}$, et al. Vascular permeability factor/vascular endothelial $\mathcal{N}$ growth factor: an important mediator of angiogenesis in malignancy and inflammation. Int Arch Allergy Immunol 1995;107:233-5

67 Claffey KP, Robinson GS. Regulation of VEGF/VPF expression in tumor cells: consequences for tumor growth and metastasis. Cancer Metastasis Rev 1996;15:165-76.

68 Paleolog E. Angiogenesis: a critical process in the pathogenesis of RA-a role for VEGF? Brf Rheumatol 1996;35:917-믄 20.

69 Thomas KA. Vascular endothelial growth factor, a potent $\vec{\bullet}$ and selective angiogenic agent. F Biol Chem 1996;271:603-6 6.

70 Fava RA, Olsen NJ, Spencer-Green G, Yeo KT, Yeo TK, Berse B, et al. Vascular permeability factor/endothelial growth factor (VPF/VEGF): accumulation and expression in human synovial fluids and rheumatoid synovial tissue. $\mathcal{F} \overline{\bar{O}}$ Exp Med 1994;180:341-6.

71 Nagashima M, Yoshino S, Ishiwata T, Asano G. Role of vascular endothelial growth factor in angiogenesis of rheumatoid arthritis. F Rheumatol 1995;22:1624-30.

72 Tanaka Y, Adams DH, Shaw S. Proteoglycans on endothe-음 lial cells present adhesion-inducing cytokines to leukocytes. Immunol Today 1993;14:111-15.

73 Kakimoto K, Nakamura T, Ishii K, Takashi T, ligou $\mathrm{H}$ Yagita $\mathrm{H}$, et al. The effect of anti-adhesion molecule antibody on the development of collagen-induced arthritis. Cellular Immunology 1992;142:326-37.

74 Issekutz AC, Issekutz TB. A major portion of polymorpho-음 nuclear leukocyte and $\mathrm{T}$ lymphocyte migration to arthritic 3 joints in the rat is via LFA-1/Mac-1-independent mecha-" nisms. Clin Immunol Immunopathol 1993;67:257-63.

75 Wahl SM, Allen JB, Hines KL, Imamichi T, Wahl AM, Furcht LT, et al. Synthetic fibronectin peptides suppress arthritis in rats by interrupting leukocyte adhesion and recruitment. $\mathcal{F}$ Clin Invest 1994;94:655-62.

76 Jorgensen C, Couret I, Canovas F, Bologna C, Brochier J Reme T, et al. Mononuclear cell retention in rheumatoid synovial tissue engrafted in severe combined immunodefi- $N$ cient (SCID) mice is up-regulated by tumour necrosis 0 factor-alpha (TNF-alpha) and mediated through intercel- $N$ lular adhesion molecule-1 (ICAM-1). Clin Exp Immunol 1996;106:20-5.

77 Kavanaugh AF, Davis LS, Nichols LA, Norris SH, Rothlein $\mathrm{R}$, Scharschmidt LA, et al. Treatment of refractory< rheumatoid arthritis with a monoclonal antibody to intercellular adhesion molecule 1. Arthritis Rheum 1994;37: 992-9.

78 Fava RA, Hunt J, Stevenson S, Nagy J, Shuto T, Esposito P, et al. Role for VEGF and flk-1 in endochondral boneT formation. Arthritis Rheum 1996;39:S272.

79 Kim KJ, Li B, Winer J, Armanini M, Gillett N, Phillips HS, $e t$ al. Inhibition of vascular endothelial growth factor-@ induced angiogenesis suppresses tumour growth in vivo. Nature 1993;362:841-4.

80 Millauer B, Shawver LK, Plate KH, Risau W, Ullrich AO Glioblastoma growth inhibited in vivo by a dominantnegative Flk-1 mutant. Nature 1994;367:576-9.

81 Aiello LP, Pierce LP, Foley ED, Takagi H, Chen H, Riddle $\mathrm{L}$, et al. Suppression of retinal neovascularization in vivo by inhibition of vascular endothelial growth factor (VEGF) using soluble VEGF-receptor chim
Acad Sci U S A 1994;92:10457-61.

82 Cheng SY, Huang HJS, Nagane M, Ji XD, Wang D, Shih $\mathrm{CCY}$, et al. Suppression of glioblastoma angiogenicity and tumorigenicity by inhibition of endogenous expression of vascular endothelial growth factor. Proc Natl Acad Sci U S A 1996;93:8502-7.

83 Wrighton CJ, Hofer-Warbinek R, Moll T, Eytner R, Bach $\mathrm{FH}$, De Martin R. Inhibition of endothelial cell activation 
by adenovirus-mediated expression of $\mathrm{IKB} \alpha$, an inhibitor of the transcription factor NF-kB. F Exp Med 1996;183:101322

84 Blake DR, Merry P, Unsworth J, Kidd BL, Outhwaite JM, Ballard $\mathrm{R}$, et al. Hypoxic-reperfusion injury in the inflamed human joint. Lancet 1989;8633:289-93.

85 Ikeda E, Achen MG, Breier G, Risau W. Hypoxia-induced transcriptional activation and increased mRNA stability of
vascular endothelial growth factor in C6 glioma cells. $\mathcal{F}$ Biol Chem 1995;270:19761-6.

86 Tuder RM, Flook BE, Voelkel NF. Increased gene expression for VEGF and the VEGF receptors KDR/Flk and Flt in lungs exposed to acute or chronic hypoxia. $f \mathrm{Clin}$ Invest 1995;95:1798-807.

87 Mukhopadhyay D, Tsiokas L, Sukhatme VP. Wild-type p53 and v-Src exert opposing influences on human vascular endothelial growth factor gene expression. Cancer Res 1995;55:6161-5.

88 Zhang Y, Deng Y, Luther T, Muller M, Ziegler R, Waldherr $\mathrm{R}$, et al. Tissue factor controls the balance of angiogenic and antiangiogenic properties of tumor cells in mice. $\mathcal{f}$ Clin Invest 1994;94:1320-7.

89 Bischoff J. Cell adhesion and angiogenesis. $f$ Clin Invest 1997;99:373-6.

90 Friedlander M, Brooks PC, Shaffer RW, Kincaid CM, Varner JA, Cheresh DA. Definition of two angiogenic pathways by distinct aV integrins. Science 1995;270:1500-2.

91 Koch AE, Halloran MM, Haskell CJ, Shah MR, Polverini PJ. Angiogenesis mediated by soluble forms of E-selectin and vascular cell adhesion molecule-1. Nature 1995;376: 517-19. 